\title{
HIBAH DAN HUBUNGANNYA DENGAN KEWARISAN MENURUT KOMPILASI HUKUM ISLAM DAN HUKUM PERDATA
}

\author{
Oleh : IBNU RUSYDI, S.H., M.Pd.I*
}

\begin{abstract}
The aim of this research is to analyze the relationship between bequest and inheritance according to compilation of Islamic law and Civil Law and to analyze the possibility abolishment of bequest when the realizing the bequest was more than one third (1/3). The result of this research are: The relatinship between bequest and inheritance according to Compilation's of Islamic Law, bequest from the parent to the children can be calculated as a part of inheritance. According to Civil Law (KUHPerdata), the bequest is a prepayment (voorschot) as a part of inheritance for legatee.
\end{abstract}

\begin{abstract}
ABSTRAK
Tujuan dari penulisan ini adalah untuk menganalisa hubungan hibah dengan kewarisan sesuai dengan Kompilasi Hukum Islam dan Hukum Perdata, dan untuk menganalisis penghapusan kemungkinan hibah ketika menyadari hibah itu lebih dari sepertiga (1/3). Hasil penulisan ini adalah: bahwa hubungan antara hibah dan kewarisan menurut Kompilasi Hukum Islam yaitu, hibah yang diberikan orang tua kepada anak-anak dapat dihitung sebagai bagian dari warisan. Menurut Hukum Perdata (KUHPerdata), hibah itu adalah prabayar (voorschot) sebagai bagian dari warisan untuk penerima waris.

Kata Kunci : Hibah dan Warisan
\end{abstract}

\footnotetext{
* Tenaga Pengajar Fakultas Hukum Universitas Galuh
} 


\section{Pendahuluan}

Menurut Kitab Undang-undang Hukum Perdata (selanjutnya disingkat KUHPerdata) Pasal 1666 menyatakan bahwa, hibah adalah suatu persetujuan dengan mana si penghibah di waktu hidupnya dengan cuma-cuma dan dengan tidak dapat ditarik kembali, menyerahkan sesuatu benda guna keperluan si penerima hibah yang menerima penyerahan itu. Penghibahan termasuk perjanjian sepihak, dimana hanya satu pihak saja yang mempunyai kewajiban atas perjanjian ini, yaitu si penghibah, sedangkan pihak yang menerima hibah sama sekali tidak mempunyai kewajiban. Penghibahan termasuk perjanjian "dengan Cuma-Cuma" (om niet) dimana perkataan "dengan Cuma-Cuma" itu ditujukan pada hanya adanya prestasi dari satu pihak saja, sedang pihak yang lainnya tidak usah memberikan kontra-prestasi sebagai imbalan. Perjanjian yang demikian, juga dinamakan "sepihak" ("unilateral") sebagai lawan dari perjanjian "bertimbal-balik" ("bilateral"). Perjanjian yang banyak tentunya adalah bertimbal-balik, karena yang lazim adalah bahwa orang yang menyanggupi suatu prestasi karena ia akan menerima suatu kontra-prestasi (R Subekti: 1995, 94-95).

Perkataan "di waktu-hidupnya" si penghibah, adalah untuk membedakan si penghibah itu dari permberian-pemberian yang dilakukan dalam suatu testament (surat wasiat), yang baru akan mempunyai kekuatan dan berlaku sesudah si pemberi meninggal dan setiap watu selama si pemberi itu masih hidup, dapat dirobah atau ditarik kembali olehnya. Pemberian dalam testament itu dalam B.W. dinamakan "legaaf" ("hibah wasiat") yang diatur dalam Hukum Waris, sedangkan penghibahan ini adalah suatu perjanjian. Karena penghibahan menurut B.W. itu adalah suatu perjanjian, maka sudah dengan sendirinya ia tidak boleh ditarik kembali secara sepihak oleh si penghibah (R Subekti: 1995, 94-95).

Menurut Kompilasi Hukum Islam (selanjutnya disingkat KHI) Pasal 171 huruf (g) dikatakan hibah pemberian sesuatu benda secara sukarela dan tanpa imbalan dari seseorang kepada orang lain yang masih hidup untuk dimiliki. Selanjutnya menurut Pasal $210 \mathrm{KHI}$ pada ayat (1) menyatakan bahwa orang yang telah berumur sekurang-kurangnya 21 tahun, berakal sehat tanpa adanya paksaan dapat menghibahkan sebanyak-banyaknya 1/3 harta bendanya kepada orang lain atau lembaga di hadapan dua orang saksi untuk dimiliki. Selanjutnya pada ayat (2) menyatakan harta benda yang dihibahkan harus merupakan hak 
dari penghibah. Dengan demikian apabila seseorang yang menghibahkan harta yang bukan merupakan haknya, maka hibahnya menjadi batal.

Berdasarkan ketentuan di atas, dapat dikatakan bahwa setiap orang boleh memberi atau menerima hibah, kecuali orang-orang yang dinyatakan tidak cakap untuk itu. Selain itu, unsur kerelaan dalam melakukan perbuatan hukum tanpa adanya paksaan dari pihak lain merupakan unsur yang harus ada dalam pelaksanaan hibah.

Selanjutnya menurut Pasal $211 \mathrm{KHI}$ menyatakan bahwa hibah dari orang tua dapat diperhitungkan sebagai warisan. Sehubungan fungsi hibah sebagai fungsi sosial yang dapat diberikan kepada siapa saja tanpa memandang ras, agama dan golongan, maka hibah dapat dijadikan sebagai solusi untuk memecahkan masalah hukum waris dewasa ini. Pasal 212 KHI menyatakan, hibah tidak dapat ditarik kembali, kecuali hibah dari orang tua kepada anaknya.

Kasus pembatalan hibah merupakan kasus yang sering terjadi dikarenakan pihak penerima hibah tidak memenuhi persyaratan dalam menjalankan hibah yang telah diberikan. Menurut hukum, hibah yang sudah diberikan tidak dapat ditarik kembali, akan tetapi terdapat beberapa pengecualian sehingga hibah dapat ditarik kembali.

Mengenai hibah di Indonesia di atur dalam beberapa ketentuan, yaitu di dalam Kompilasi Hukum Islam (KHI), Hukum Adat dan Kitab Undang-Undang Hukum Perdata (KUHPerdata). Dari ketentuan-ketentuan tersebut, hibah merupakan suatu solusi dalam pembagian warisan kepada keluarganya.

Konsentrasi pembahasan dalam tulisan ini adalah mengenai hubungan hibah dengan kewarisan menurut KHI dan Hukum Perdata.

\section{Pembahasan}

\subsection{Hibah menurut $\mathrm{KHI}$}

Sebagaimana telah diuraikan bahwa hibah, merupakan pemberian dari seseorang pemberi hibah kepada orang lain sebagai penerima hibah ketika si pemberi hibah (yang punya harta) masih hidup, sedangkan warisan diberikan ketika si pewaris (yang punya harta) telah meninggal dunia. Walaupun waktu pemberiannya berbeda namun keduanya memiliki hubungan yang sangat erat. terutama hibah itu diberikan kepada anak atau ahli waris karena akan menentukan terhadap bagian warisan yang akan 
diterimanya. Menurut Pasal $211 \mathrm{KHI}$ bahwa hibah yang diberikan orang tua kepada anaknya dapat diperhitungkan sebagai warisan.

Memang, prinsip pelaksanaan hibah orang tua kepada anak sesuai dengan petunjuk Rasulullah saw yakni hendaknya bagian mereka disamakan. Kalaupun dibedakan, hanya bisa dilakukan jika mereka saling menyetujuinya. Oleh karena itu adanya perbedaan pendapat tentang status hukum melebihkan hibah kepada satu anak, tidak kepada orang lain, yang terpenting dalam pemberian hibah tersebut adalah dilakukan secara musyawarah dan atas persetujuan anak-anak yang ada. Hal ini penting agar tidak terjadi perpecahan dalam keluarga.

Dengan demikian dapat ditegaskan bahwa pemberian hibah dapat diperhitungkan sebagai warisan. Boleh jadi, pola pembagian demikian, oleh sementara pendapat dianggap sebagai sikap mendua umat Islam di Indonesia menghadapi soal warisan. Di satu sisi menghendaki hukum waris Islam dilaksanakan, namun realisasinya telah ditempuh secara hibah, justru sebelum si pewaris meninggal dunia. Bahwa kemudian KHI, menegaskan demikian, kelihatannya didasari oleh kebiasaan yang dianggap "positif" oleh masyarakat. Karena, bukanlah sesuatu yang aneh, apabila pembagian harta waris, dilakukan akan menimbulkan penderitaan pihak tertentu, lebihlebih apabila penyelesaiannya dalam bentuk gugatan di pengadilan.

Kadang-kadang hibah yang diberikan kepada sebagian ahli waris diikuti dengan perjanjian, bahwa apabila ia sudah menerima hibah dalam jumlah tertentu, ia berjanji tidak akan meminta bagian warisan kelak jika si pemberi hibah meninggal dunia. Perjanjian semacam ini disebut dengan pengunduran diri (takharruj). Fatchur Rahman mendefinisikan Takharuj adalah suatu perjanjian yang diadakan oleh para ahli waris untuk mengundurkan diri (mengeluarkan) salah seorang ahli waris dalam menerima bagian pusaka dengan memberikan suatu prestasi, baik prestasi tersebut berasal dari harta milik orang yang pada mengundurkannya, maupun berasal dari harta peniggalan yang bakal dibagi-bagikan (Fathur Rahman dalam Ahmad Rofiq: 2000, 474)

Takharruj merupakan transaksi antara dua pihak atau lebih, satu pihak menyerahkan sesuatu sebagai pihak lain, dan pihak lain 
menyerahkan bagian warisnya sebagai tegenprestasi kepada pihak petama.

Persoalannya sekarang, perlu diidentifikasikan agar jelas, apakah hibah yang diberikan seseorang kepada anak-anaknya itu dianggap sebagai warisan, ataukah sebagai hibah biasa sebab keduanya memiliki implikasi hukum yang berbeda. Pertama, apabila hibah itu diperhitungkan sebagai warisan, maka sangat tergantung pada kesepakatan anakanaknya, atau diperhitungkan menurut sistem kewarisan, karena seperti diutarakan oleh Umar ibn al-Khattab bahwa perdamaian justru lebih baik, daripada nantinya harus melibatkan pengadilan. Kedua, apabila pemberian itu dinyatakan sebagai hibah saja, maka menurut petunjuk Rasulullah saw, pembagiannya harus rata. Ini ditegaskan oleh tindakan Rasulullah saw, "jika anak-anakmu yang lain tidak engkau beri dengan pemberian yang sama, maka tarik kembali hibah tersebut" (Ahmad Rofiq: 2000, 475).

Sebagaimana diketahui bahwa hukum waris Islam apabila diterapkan sesuai dengan ketentuan kitab figh klasik masih menimbulkan berbagai masalah bila dihadapkan dengan realitas sosial masyarakat Indonesia, antara lain:

a. Adanya kecenderungan sebagian masyarakat Indonesia yang tidak ingin membedakan hak waris anak laki-laki dengan anak perempuan.

Hak waris anak laki-laki dan anak perempuan adalah 2:1 dianggap sudah final karena landasan hukumnya qath'i al-wurud dan qat'i al-dilalah (dalil yang pasti yakni dari Al-Qur'an dan Sunnah Rasulullah SAW) sehingga tidak bisa ditafsirkan lain, tetapi kenyataan masyarakat muslim Indonesia ada kecenderungan tidak ingin membeda-bedakan pemberiannya baik terhadap anak laki-laki maupun anak perempuan, terlebih lagi dengan adanya isu kesetaraan gender, yang berimplikasi terhadap pembagian harta warisan dengan tidak membeda-bedakan hak anak laki-laki dan anak perempuan, adapun kalangan masyarakat muslim yang tetap konsisten melakukan pembagian warisan 2:1 sepertinya lebih cenderung kepada bentuk kepatuhan dan ketaatannya terhadap ajaran agama, bukan dilandasi oleh kesadaran hukumnya. 
Sehubungan dengan itu banyak kalangan masyarakat muslim yang taat terhadap agamanya membagi-bagikan harta mereka sewaktu masih hidup kepada anak-anaknya, tanpa membeda-bedakan bagian anak laki- laki dan perempuan sehingga yang menjadi harta warisan hanya sebagian kecil saja. Hal ini tiada lain hanyalah sebagai bentuk "menghindari" pembagian dari sistem bagi waris $2: 1$ dan lebih mengarah kepada pembagian warisan $1: 1$.

Membagi-bagikan harta dengan bentuk hibah sewaktu pewaris masih hidup, dengan maksud dan tujuan agar bagian anak laki-laki dan anak perempuan memperoleh bagian yang sama tidak dapat disalahkan, bahkan hal itu merupakan sebuah solusi dalam hukum waris Islam, bahkan ada riwayat dari Ibn Abas R.A. katanya, Nabi saw pernah bersabda yang artinya sebagai berikut:

"Samakanlah pemberian yang kamu lakukan terhadap anakanakmu; dan sekiranya hendak melebihkan, maka hendaklah kelebihan itu diberikan kepada anak perempuan". (HR. Bayhaqi : 1994, Juz 6, 177).

Berdasarkan uraian tersebut di atas dapat dipahami bahwa hibah yang diberikan oleh si pemberi hibah pada waktu masih hidup dapat dijadikan solusi dalam pembagian harta warisan kepada ahli warisnya.

b. Ahli waris non muslim tidak menjadi ahli waris dari pewaris muslim sehingga tidak akan mendapat harta warisan.

Dasar hukum ahli waris non muslim tidak mewarisi pewaris muslim adalah hadits dari Usamah bin Zaid, bahwa Nabi saw bersabda yang artinya: "Seorang muslim tidak mewarisi dari seorang kafir, (demikian juga) seorang kafir tidak mewarisi dari seorang muslim". (Sayyid Sabiq : 1997, 261).

Menurut hukum waris Islam yang selama ini diterapkan di lingkungan Peradilan Agama, ahli waris non muslim tidak akan mendapat harta warisan dari pewarisnya yang muslim atas dasar hadis di atas. Demikin juga pasal 171 huruf (b) dan (c) KHI, menyatakan bahwa pewaris dan ahli waris harus beragama Islam.

Apabila hal tersebut di atas tetap dipertahankan maka ada semacam ketidakadilan hukum yang perlu dicarikan solusinya, di antara 
solusinya adalah dengan hibah yang harus diberikan oleh orang tua (pewaris muslim) ketika masih hidup kepada ahli warisnya yang non muslim agar kegoncangan sosial dalam sebuah keluarga dapat dihindari.

c. Anak angkat dan orang tuaangkat tidak saling mewarisi karena tidak memiliki hubungan kekerabatan.

Sebagaimana diatur dalam Pasal 209 ayat (1) KHI bahwa harta peninggalan anak angkat dibagi berdasarkan Pasal-pasal 176 sampai dengan $193 \mathrm{KHI}$, sedangkan terhadap orang tua angkat yang tidak menerima wasiat, diberi wasiat wajibah sebanyak-banyaknya 1/3 dari harta warisan anak angkatnya. Selanjutnya pada ayat (2) KHI bahwa terhadap anak angkat yang tidak menerima wasiat wajibah sebanyak-banyaknya diberikan kepadanya $1 / 3$ dari harta warisan orang tua angkatnya.

Berkaitan dengan masalah di atas Pasal $211 \mathrm{KHI}$ telah memberikan solusi, yaitu dengan cara hibah yang diberikan orang tua kepada anaknya dapat diperhitungkan sebagai warisan. Pengertian "dapat " dalam pasal tersebut bukan berarti imperatif (harus), tetapi merupakan salah satu alternatif yang dapat ditempuh untuk menyelesaikan perselisihan atau sengketa warisan. Oleh karena itu, sepanjang par ahli waris tidak ada yang mempersoalkan hibah yang sudah diterima oleh sebagian ahli waris, maka harta warisan yang belum dihibahkan dapat dibagikan kepada semua ahli waris sesuai dengan bagiannya masing-masing. Tetapi apabila ada sebagian ahli waris yang mempersoalkan hibah yang diberikan kepada sebagian ahli waris lainnya, maka hibah tersebut dapat diperhitungkan sebagai harta warisan, dengan cara memperhitungkan hibah yang sudah diterima dengan bagian warisan yang seharusnya diterima.

Apabila hibah yang sudah diterima masih kurang dari bagian warisan maka tinggal menambah kekurangannya, dan sebaliknya apabila hibah tersebut melebihi dari bagian warisan maka kelebihan hibah tersebut dapat ditarik kembali untuk diserahkan kepada ahli waris yang kekurangan dari bagiannya. 


\subsection{Hibah menurut KUH Perdata}

Sebagaimana yang telah diuraikan terdahulu bahwa Inbreng (Pemasukan) adalah memperhitungkan pemberian barang-barang yang dilakukan oleh orang yang meninggalkan harta warisan pada waktu ia masih hidup kepada para ahli waris (Wiriono Prodjodikoro dalam Idris Ramulyo: 2004, 126). Semua hibah-hibah yang pernah diberi pewaris kepada para ahli waris dalam garis lurus ke bawah (anak cucu dan seterusnya) kecuali kalau pewaris secara tegas membebaskan mereka dari pemasukan, seakan-akan merupakan persekot (uang muka) atas bagian para ahli waris dalam harta peninggalan pewaris (Soerojo Wongsowidjojo dalam Idris Ramulyo: 20014, 126).

Inbreng (Pemasukan) diatur dalam Pasal 1086 s.d. 1099 KUHPerdata. Perhitungan itu harus dilakukan ahli waris keturunan dari orang yang meninggalkan harta warisan yaitu anak, cucu, dan seterusnya ke bawah, kecuali bilamana orang yang meninggalkan harta warisan secara tegas membebaskan mereka dari perhitungan ini, sedang perhitungan itu oleh waris lain hanya meski dilaksanakan, bilamana ini dikehendaki oleh orang yang meninggalkan harta warisan.

Apabila perhitungan ini dilaksanakan, maka pemberian-pemberian yang dulu dilakukan oleh orang yang meningggalkan harta warisan selama ia masih hidup, dianggap sebagai pemberian di depan (voorschot) dari bagian si ahli waris itu dalam harta warisan.

Adapun yang harus diperhitungkan adalah: seluruh penghibahan (schenkingen) oleh orang yang meninggalkan harta warisan pada waktu ia masih hidup. Menurut Jurisprudensi dari Hoge Raad di Negeri Belanda, penghibahan ini mencakup juga lain-lain perbuatan yang

juga menguntungkan ahli waris, seperti pembebasan utang, sebagaimana diatur pada Pasal 1086 KUHPerdata.

Berdasarkan uraian tersebut di atas, maka jelaslah bahwa hibah mempunyai hubungan yang erat dengan pembagian waris adalah karena adanya pemasukan (inbreng). Apabila pewaris pada waktu masih hidupnya telah memberikan benda-benda secara hibah (schenking) kepada ahli waris, karena pemberian semacam itu dapat dianggap sebagai uang muka atas bagian warisan yang akan diperhitungkan kemudian. Hal ini 
tidak dibedakan apakah mereka itu menerima warisannya secara penuh atau menerima dengan bersyarat.

\subsection{Pembatalan Hibah menurut KHI}

Menurut Pasal $211 \mathrm{KHI}$ menyatakan, bahwa hibah tidak dapat ditarik kembali, kecuali hibah orang tua kepada anaknya.

Pembatalan atau penarikan kembali atas suatu pemberian (hibah) merupakan perbuatan yang diharamkan, meskipun hibah tersebut terjadi antara dua orang yang bersaudara atau suami isteri. Adapun hibah yang boleh ditarik kembali hanyalah hibah yang dilakukan atau diberikan orang tua kepada anaknya.

Menurut hadis dari Ibnu Abbas bahwa Rasulullah saw bersabda yang artinya : "bahwa orang yang meminta kembali hibahnya adalah laksana anjing yang muntah kemudian dia memakan kembali muntahnya itu". (HR. Muslim: 2000, juz 3, 1240) Dalam riwayat yang lain, Ibnu Umar dan Ibnu Abbas mengemukakan bahwa Rasulullah pernah berkata yang artinya: "tidak halal bagi seorang muslim yang memberikan suatu pemberian kemudian ia meminta kembali pemberiannya itu, kecuali orang tua dalam suatu pemberian yang ia berikan kepada anaknya" (HR. Tirmidzi, Ibnu Hibban, Al Hakim, An Nasa' dan Ibnu Majah)

Namun demikian kalaupun tertutup kemungkinan untuk menarik kembali suatu barang yang telah dihibahkan (menurut sebagian pendapat kecuali hibah yang diberikan terhadap anak), penarikan itu dapat juga dilakukan seandainya hibah yang diberikan tersebut guna mendapatkan imbalan dan balasan atas hibah yang diberikannya. Misalnya seseorang yang telah berusia lanjut memberikan hibah kepada seseorang tertentu, dengan harapan kiranya si penerima hibah memeliharannya, akan tetapi setelah hibahnya dilaksanakan, si penerima hibah tidak memperhatikan keadaan si pemberi hibah. Maka dalam hal seperti ini si penerima hibah dapat menarik kembali hibah yang telah diberikannya.

Ketentuan hukum tentang hal ini dapat dipedomani hadis yang diriwayatkan oleh Salim dari ayahnya, dari Rasulullah saw., beliau bersabda yang artinya sebagai berikut: "barang siapa hendak memberi suatu hibah, maka ia lebih berhak terhadapnya selama ia belum dibalas". 
$\mathrm{KHI}$ menganut prinsip bahwa hibah hanya boleh dilakukan 1/3 dari harta yang dimilikinya, hibah orang tua kepada anaknya dapat diperhitungkan sebagai waris.

Apabila hibah dilaksanakan menyimpang dari ketentuan tersebut, maksudnya yaitu diharapkan agar tidak terjadi perpecahan diantara keluarga. Prinsip yang dianut oleh hukum Islam adalah sesuai dengan kultur bangsa Indonesia dan sesuai pula dengan apa yang dikemukakan oleh Muhammad bin Hasan, bahwa orang yang menghibahkan semua hartanya itu adalah orang yang dungu dan tidak layak bertindak hukum. Oleh karena orang yang menghibahkan harta dianggap tidak cakap bertindak hukum, maka hibah yang dilaksanakan dianggap batal, sebab ia tidak memenuhi syarat untuk melakukan penghibahan. (Abdul Manan: 2008, 138)

Sehubungan dengan uraian tersebut di atas dapat dikemukakan bahwa pada prinsipnya hibah tidak dapat dibatalkan atau ditarik kembali, namun apabila hibah yang diberikan seseorang pemberi hibah yang melebihi 1/3 dari harta kekayaannya, maka hibah dapat dibatalkan, karena tidak memenuhi syarat dalam penghibahan serta melanggar ketentuan sebagaimana diatur dalam Pasal $210 \mathrm{KHI}$.

\subsection{Pembatalan Hibah menurut KUH Perdata}

Menurut KUHPerdata, tidak ada ketentuan yang memberikan pembatasan tentang hibah yang diberikan si pemberi hibah sebagaimana yang diatur dalam KHI. Pada prinsipnya hibah yang telah diberikan oleh seseorang kepada orang lain tidak dapat ditarik kembali atau dibatalkan, kecuali dalam hal-hal sebagaimana yang diatur dalam Pasal 1688 KUHPerdata, yaitu :

a. Jika syarat-syarat penghibahan itu tidak dipenuhi oleh penerima hibah

Dalam hal ini barang yang dihibahkan tetap tinggal pada penghibah, atau ia boleh meminta kembali barang itu, bebas dari semua beban dan hipotek yang mungkin diletakkan atas barang itu oleh penerima hibah serta hasil dan buah yang telah dinikmati oleh penerima hibah sejak ia alpa dalam memenuhi syarat-syarat penghibahan itu. Dalam hal demikian penghibah boleh menjalankan 
hak-haknya terhadap pihak ketiga yang memegang barang tak bergerak yang telah dihibahkan sebagaimana terhadap penerima hibah sendiri.

b. Jika orang yang diberi hibah bersalah dengan melakukan atau ikut melakukan suatu usaha pembunuhan atau suatu kejahatan lain atas diri penghibah.

Dalam hal ini barang yang telah dihibahkan tidak boleh diganggu gugat jika barang itu hendak atau telah dipindahtangankan, dihipotekkan atau dibebani dengan hak kebendaan lain oleh penerima hibah, kecuali kalau gugatan untuk membatalkan penghibahan itu sudah diajukan kepada dan didaftarkan di Pengadilan dan dimasukkan dalam pengumuman tersebut dalam Pasal 616 KUHPerdata. Semua pemindahtanganan, penghipotekan atau pembebanan lain yang dilakukan oleh penerima hibah sesudah pendaftaran tersebut adalah batal, bila gugatan itu kemudian dimenangkan.

c. Jika penghibah jatuh miskin sedang yang diberi hibah menolak untuk memberi nafkah kepadanya.

Dalam hal ini barang yang telah diserahkan kepada penghibah akan tetapi penerima hibah tidak memberikan nafkah, sehingga hibah yang telah diberikan dapat dicabut atau ditarik kembali karena tidak dilakukannya pemberian nafkah.

\section{Penutup}

\subsection{Kesimpulan}

Berdasarkan uraian di atas, maka dapat disimpulkan sebagai berikut :

a. Hubungan hibah dengan kewarisan menurut $\mathrm{KHI}$, dimana hibah yang telah diberikan orang tua kepada anaknya dapat diperhitungkan sebagai warisan. Sedangkan menurut KUH Perdata pemberian yang dilakukan oleh orang yang meningggalkan harta warisan pada waktu masih hidup, dianggap sebagai pemberian didepan (voorschot) dalam harta warisan dari bagian si ahli waris.

b. Menurut KHI, bahwa pada dasarnya hibah tidak dapat dibatalkan atau ditarik kembali, kecuali hibah orang tua kepada anaknya. Begitu pula menurut KUH Perdata bahwa hibah yang telah diberikan oleh 
seseorang kepada orang lain tidak dapat ditarik kembali atau dibatalkan, kecuali: (a) Jika syarat-syarat penghibahan itu tidak dipenuhi oleh penerima hibah, (b) Jika orang yang diberi hibah bersalah dengan melakukan atau ikut melakukan suatu usaha pembunuhan atau suatu kejahatan lain atas diri penghibah, (c) Jika penghibah jatuh miskin sedang yang diberi hibah menolak untuk memberi nafkah kepadanya.

\subsection{Saran}

a. Hendaknya proses penghibahan dari pemberi hibah kepada penerima hibah melibatkan calon ahli waris, agar tidak menimbulkan perselisihan dikemudian hari.

b. Hendaknya Pejabat yang membuat akta hibah memperhatikan rukun dan syarat hibah, agar jangan sampai terjadi pembatalan hibah dikarenakan tidak dipenuhinya rukun dan syarat hibah tersebut. 


\section{Daftar Pustaka}

Bayhaqi, Sunan al-Bayhaqi al-Kubra, Dar al-Baz, 1994.

Manan, Abdul, Aneka Masalah Hukum Perdata Islam di Indonesia, Prenada Media Group, Jakarta, 2008.

Muslim, Shahih Muslim, Dar Ihya Turas, Beirut, 2000.

Ramulyo, Idris, Perbandingan Hukum Kewarisan Islam Dengan Kewarisan Kitab Undang-undang Hukum Perdata, Sinar Grafika, Jakarta, 2004.

Rofiq, Ahmad, Hukum Islam Di Indonesia, PT. Raja Grafindo Persada, Jakarta, 2000.

Sabiq, Sayyid, Fiqh Sunnah Edisi ke-14, Al-Ma'arif, Bandung, 1997.

Subekti, Aneka Perjanjian, Citra Aditya Bakti, Bandung, 1995.

Kitab Undang-undang Hukum Perdata.

Instruksi Presiden No. 1 Tahun 1991 tentang Kompilasi Hukum Islam. 